Hat fo. e $x^{2}$ todocit osta $0.00^{3}$

di $04 \div 82020$ 400535

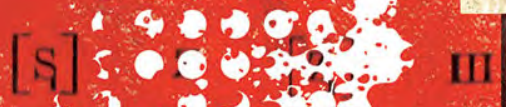
w t f t lt

t. (1) 9 o $[0] \quad q \quad 4$

III II, IP $\mathrm{I} \mathrm{d}_{1} \mathrm{~b}$ k $\mathrm{k}_{\mathrm{a}}-1 \mathrm{~s}$

8

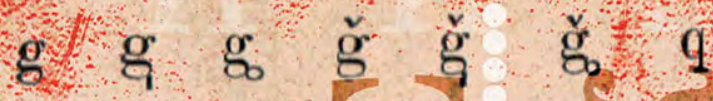

i $\quad \dot{q}, \dot{c}]\left[q_{0}\right.$ h $r, 1][1]$

n $[\mathrm{n}]$
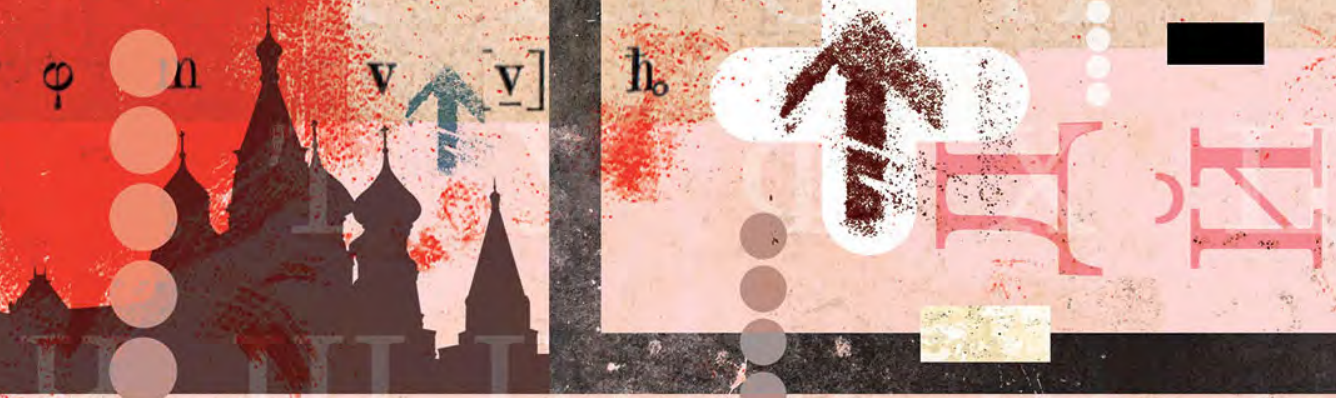

즈 $\bigcirc$

.
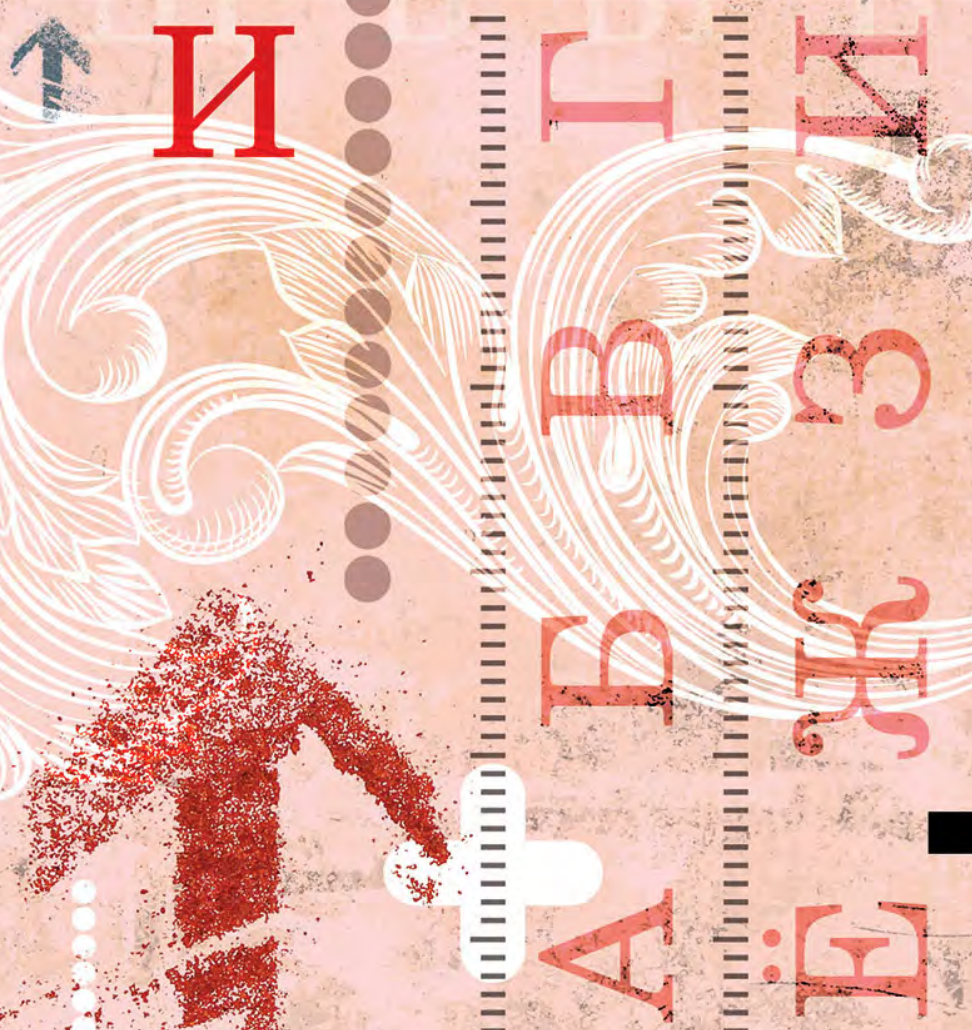


\title{
The role of state in the banking industry: Evidence from Russia
}

\author{
O papel do Estado no setor bancário: \\ Evidências da Rússia
}

* Andrei Vernikov

\begin{abstract}
The article examines the role of the state in the Russian banking industry. Statistical data illustrates the market share of public banks and its dynamics over the past 25 years. We show the impact of public banks on the lending to non-financial companies, and particularly longerterm lending. Empirical findings suggest that it terms of profitability and technical efficiency the core public banks are not necessarily worse than privately held institutions. Finally, the author compares the macro-level structure and the core institutions of the banking systems in China and Russia and suggests that these are typologically more similar than different.
\end{abstract}

Keywords: Russia; banks; government; public sector; state-controlled banks

\begin{abstract}
Resumo
Este artigo examina o papel do Estado no setor bancário russo. Os dados estatísticos ilustram a participação dos bancos públicos e sua dinâmica de mercado nos últimos 25 anos. Mostramos o impacto dos bancos públicos na concessão de empréstimos à empresas não financeiras e, particularmente, os empréstimos de longo prazo. Os resultados empíricos sugerem que os termos de rentabilidade e eficiência técnica dos bancos públicos não são necessariamente piores do que as instituições privadas. Finalmente, o autor compara a estrutura macro-nível e as instituições centrais dos sistemas bancários na China e na Rússia e sugere que estas são tipologicamente mais similares do que diferentes.
\end{abstract}

Palavras-chave: Russia, bancos, governo, setor público, bancos estatais 


\section{Introduction}

$\mathrm{T}$ he trajectory of the Russian baking industry over the past 25 years was far from linear: a meltdown of the public sector was then reversed, and the initial boom in the private sector was followed by its collapse and subsequent agony over 15 years or so. Distinctly from other transition economies in Europe, foreign banks do not control a sizeable share of the market and currently even see their market share shrinking.

In this paper I intend to shed some light on the size and scope of the public sector in the Russian banking industry, with a focus on the heterogeneity within statecontrolled banks and the need to avoid excessive aggregation. Another motivation is to confront the trends in the market share of state banks with those in the loansto-assets ratio and the share of longer-term loans in the loan portfolio. The intuitive assumption is that these trends are correlated. I try to bring the activity of the Russian development bank into the scope for the first time, because previous research has completely missed the topic due to specific coverage by Russian banking statistics.

Contributing to the debate on bank ownership/performance nexus, I bring evidence from Russia to challenge the theoretical predictions about negative contribution of public banks to bank effectiveness and efficiency. Private financial intermediaries clearly failed to perform properly as providers of funding for economic growth and yielded way to public institutions that, counter-intuitively, display profitability and efficiency not inferior than their private peers.

In an attempt to place the Russian evidence into a broader socio-economic context, I refer a comparative study of the commercial banking systems in Russia and in China. The hypothesis is that China serves as an appropriate benchmark for Russia in this particular field, as the two banking industries turn out to be more alike than different in their essential institutions.

Correspondingly, the rest of this paper is organized as follows. The first section features the market share of public banks in the Russian banking industry. The second section describes the lending activity of banks depending on their ownership form. The third section assesses profitability and efficiency of state banks. The fourth section compares the main institutional features of the banking industry in China and Russia. The last section concludes.

\section{The size of the public sector within the banking industry}

Studying the impact of ownership type on bank performance requires an accurate identification of institutions pertaining each of the ownership forms, in this case public ownership. I use various sources to trace public funds in the equity of Russian banks, namely the websites of the banks themselves, Central Bank of Russia (CBR), Bankscope, Banker's Almanac, etc. The sample includes banks where an identifiable public entity (-ies) owns a $50 \%$ or higher share directly or indirectly. In the Russian case, the type 
of a public entity may vary from the federal government to industrial companies and banks whose equity contains public funds [Vernikov, 2012; 2015b]. The total number of state-controlled banks floats between 38 and 54 (currently 42), and I trust that the coverage is the broadest available.

Public sector went into decay in the 1990s and soon shrunk to nearly onethird of total banking assets. The system of specialized state banks ('spetsbanki') was abandoned to looting by insiders and demolition [Schoors, 2003]. Soon after the financial crisis of 1998 the remaining public banks as well as new ones started regaining market positions, and after a period of incremental growth their market share approached $60 \%$ (Fig.1).

The gap between the CBR-reported market share of state-controlled banks and our estimate was quite broad at earlier stages of observations but shrank to a mere 2.5 percentage points by January 1,2015 . I attribute the existence of such a gap to discrepancies in the coverage, the main one being the treatment of banks controlled by state-owned industrial enterprises: I have always included them, and the CBR apparently have not. The inclusion or non-inclusion of banks majority-owned by public banks and non-financial companies is a methodological, rather than a merely technical, issue. I opt to include them in order to reflect the true magnitude of the public sector in the Russian banking industry. However, the notion of state control might appear as far-fetched because I recognize that the government has limited capacity to control the activity of downstream entities in the corporate pyramids that public banks and companies have designed. The capital structure might be out of coherence with the governance structure in the sense that a predominant equity stake may not automatically give its holder control over the company, especially in

Fig. 1 - Alternative estimates of the market share of state-controlled banks in Russia (as \% of total banking assets by respective year-end)

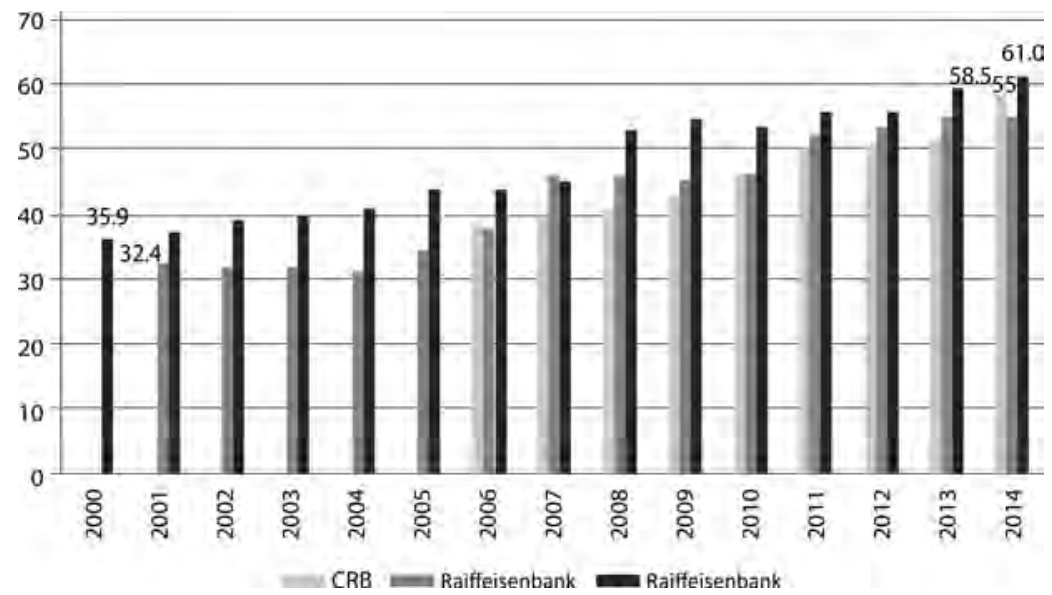

Sources: CBR (2015); Raiffeisenbank (2015); same sources for respective years; own calculations; Vernikov (2015b) 
jurisdictions with less than perfect corporate governance. The whole purpose of replacing direct state ownership by indirect holding often is to withdraw the company from the external control and thus enable the appropriation by insiders. There have been multiple cases when nominally state-owned entities fall under the influence of insiders at the expense of shareholders. State control therefore remains a convention.

Russia's state-controlled banks are too numerous, their business models too diverse, and their market share too large to be treated as a single group. This industry structure warrants for the introduction of additional sub-categories of state-controlled banks for the sake of a more accurate assessment of their activity and performance and a greater homogeneity within each of the groups. Similarly, when studying the Chinese banking sector, some scholars analyze the "Big 4" or "Big 5" state banks separately from all other banks [Berger, Hasan, Zhou, 2009] whose absolute majority are also controlled by the state. So do China's official banking statistics [CBRC, 2014]. In Russia one can distinguish between the three "national champions" (Sberbank of Russia, VTB, and Russian Agricultural Bank) that jointly control $42 \%$ of all banking sector assets, and other state-controlled banks whose market share is in the order of $19 \%$. The difference between them is more essential than just average size of institutions. The three largest state banks often act as government agents and pursue a combination of financial and non-financial objectives [Vernikov, 2014a], whereas many of the smaller statecontrolled banks, particularly indirectly-owned banks, display market behavior similar to private domestic institutions. They are typically excused from on-lending of public funds to government-supported projects.

The nominal share of state ownership explains some, but not all developments in the banking sector. The government has many tools, apart from direct equity participation, to influence banks and companies, namely public procurement, liquidity allocation, access to national projects, and award of service contracts for public sector entities. Nominally private or foreign banks can be encouraged to act in concert with the government bodies or selected clans of civil servants. There are also opposite examples, of nominally state-owned banks that fall under the control of their managers and other insiders and change the operational regime.

The share of state banks varies depending on the market segment. As far as loans to non-financial private sector are concerned, the market share of state banks is $64.2 \%$ [CBR, 2015, p.21], i.e. slightly higher than in total assets. Russian official banking statistics covers only commercial banks and leaves beyond coverage an important market segment, namely development lending performed by the Bank for Development and Foreign Economic Activity (Vneshekonombank) that legally is beyond the banking system. The addition of the development loan portfolio of Vneshekonombank would increase the share of state banks in the loan market by more than 2 percentage points to (own calculation).

According to the Central Bank of Russia, state-controlled banks maintain $60.4 \%$ of all household deposits [CBR, 2015, p.19]. Despite low level of trust toward them, 
domestic private banks still hold one-third of household deposits, to a large extent as a result of the deposit insurance scheme that erodes market discipline of the depositors and promotes moral hazard [Karas, Pyle, Schoors, 2013].

\section{Productive lending vs. speculation}

The predominantly private banking system that emerged in the 1990s failed to deliver on the main functions of financial intermediation: it neither provided financing to the productive sectors of the economy, nor enjoyed enough trust to accumulate private sector savings. The loans-to-assets ratio has declined to nearly $30 \%$ (Fig.2). Instead of loans, the banks were investing into government securities whose share in total assets reached $32.1 \%$ by the middle of 1998 , i.e. right before the financial crisis [CBR, 2002, p.10]. Banks were effectively taking advantage of Russia's fiscal weaknesses and clipping coupons instead of lending.

The loans-to-assets ratio recovered quickly after 1999, in parallel with the growing market share of state banks. It prompts the hypothesis that the activity of public banks contributes more to financial depth than that of other market participants, contrary to the negative predictions of [La Porta, López-de-Silanes and Shleifer, 2002]. The upward trend somewhat reversed after the financial turmoil in 2008-2009, reflecting the limited capacity and appetite to lend among banks across the board.

Researchers have long been studying the causality between bank activity and economic growth [King, Levine, 1993]. It has been proven empirically that bank activity is a good predictor of growth, but the causality there fails to receive convincing statistical proof in a variety of country cases. The reason may be that the gross volume

Fig.2 - The loans-to-assets ratio of Russian banks

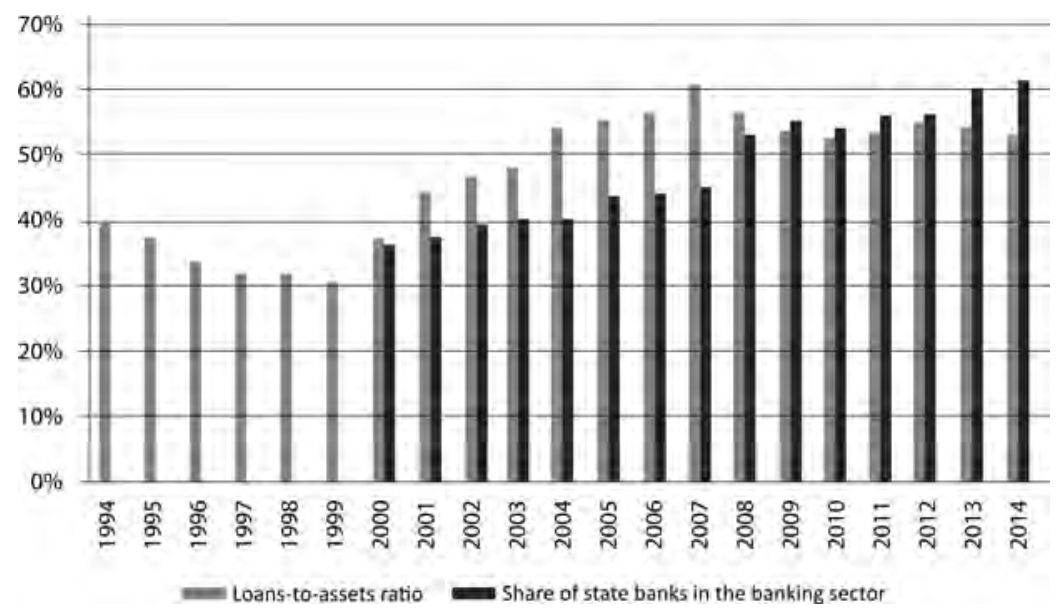

Source: (entral Bank of Russia; own calculation (the share of state banks) 
of outstanding loans (and especially total bank assets) as a ratio of the gross domestic product (GDP) are overly aggregated measures of bank activity. Neither all kinds of banking operations nor all bank debt of the non-financial private sector are good for longer-term development and growth: bank loans can just as well support overinvestment, over-consumption and speculation [Bezemer, 2014]. Following Joseph Schumpeter's ideas about the role of credit in financing productive innovations [Schumpeter, 1934], Bezemer proposes to distinguish between debts according to purpose and to focus on the volume of credit financing development.

While banks are by far the most important type of financial intermediary in Russia and bank loans are the main external source of financing, the role of bank loans as a source of investment into fixed assets by non-financial companies remains quite limited. According to the Federal Statistical Service, this indicator at its lower peak in 2000 read only $2.3 \%$ (Fig.3). It still remains under $10 \%{ }^{2}$

Building on the insightful recommendation of [Bezemer, 2014], I try to identify the part of bank lending that goes to finance investment and innovation, as opposed to working capital financing, speculation, etc. Vneshekonombank, the development bank, discloses the amount of its investment lending that makes up nearly $90 \%$ of the loan portfolio. Russian commercial banks do not report investment loans separately, so one can only assume indirectly which flows of credit go to finance a certain purpose. Data on the allocation of loans among sectors is only available on aggregated basis, while on individual bank level the breakdown by sector is usually too general, or inaccurate, or even distorted (e.g., the financing of a commercial development project presented

Fig.3 - Domestic bank loans as a source of non-financial companies' investment into fixed assets in Russia

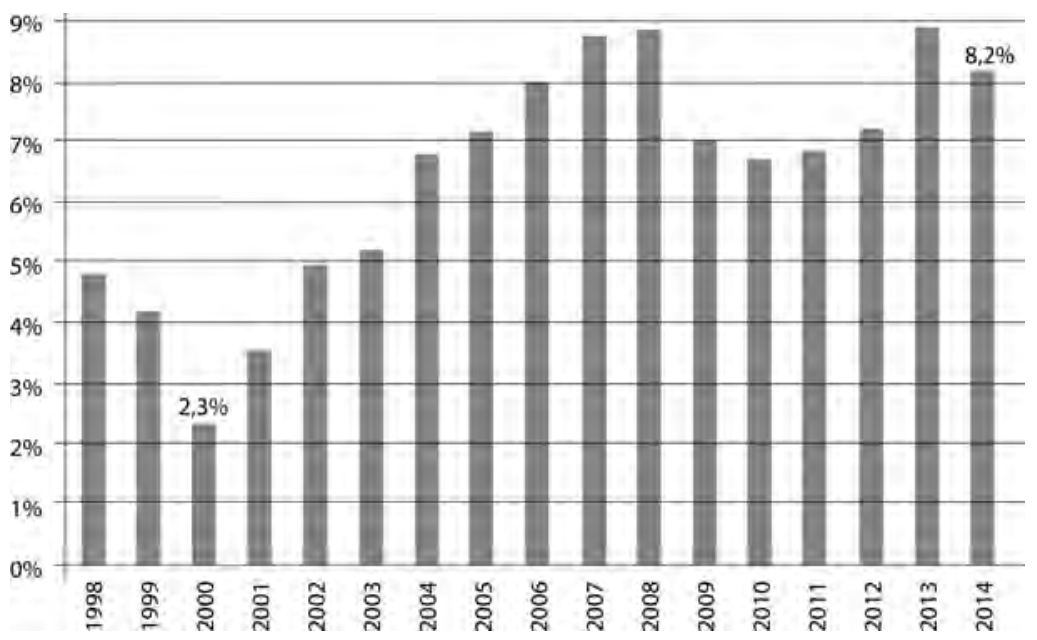

Source: Rosstat (www.gks.ru) 
as a diversified corporate loan portfolio to several firms engaged in unrelated businesses, in order to circumvent the single obligor limit). I thus opt to use loans with maturities of more than 3 years as a proxy for investment lending, on the assumption that working capital financing usually implies tenors shorter than that. I admit that longer tenors might be a less than perfect proxy for investment lending because they can denote a variety of phenomena such as related lending to own or'pet' businesses, poor loan quality, etc.

The share of longer-term loans in the total lending by Russian commercial banks to non-financial entities has gradually grown to almost 50\% (Tab.1), partly reflecting the systemic reasons mentioned above. Vneshekonombank, whose mission is to promote development and investment, dedicates a much higher share of its loan portfolio to long-term lending, almost $98 \%$. Currently Vneshekonombank contributes roughly onetenth of long-term loans, but its relevance keeps growing.

Average numbers hide different performance by different types of banks. While longer-term loans prevail in the loan portfolio of state banks with an upward trend, the indicators for other bank groups lag behind or even decline (Fig.4).

Table 1 - The significance of longer-term loans (over 3 years) and investment loans

\begin{tabular}{l|c|c|c|c}
\hline & \multicolumn{2}{|c|}{ Commercial banks } & \multicolumn{2}{c}{ Vneshekonombank } \\
\hline & 2013 & 2014 & 2013 & 2014 \\
\hline Longer term loans / total loans & 0.45 & 0.495 & 0.977 & 0.977 \\
\hline Longer term loans / GDP & 0.15 & 0.205 & 0.019 & 0.019 \\
\hline Investment loans / total loans & $\ldots$ & $\ldots$ & 0.916 & $\ldots$ \\
\hline Investment loans / GDP & $\ldots$ & $\ldots$ & 0.013 & $0.017^{*}$ \\
\hline * preliminary estimate \\
Sources: Central Bank of Russia; Vneshekonombank
\end{tabular}

Fig. 4 - The share of longer term loans (over 3 years) in total loans to non-financial enterprises, \%

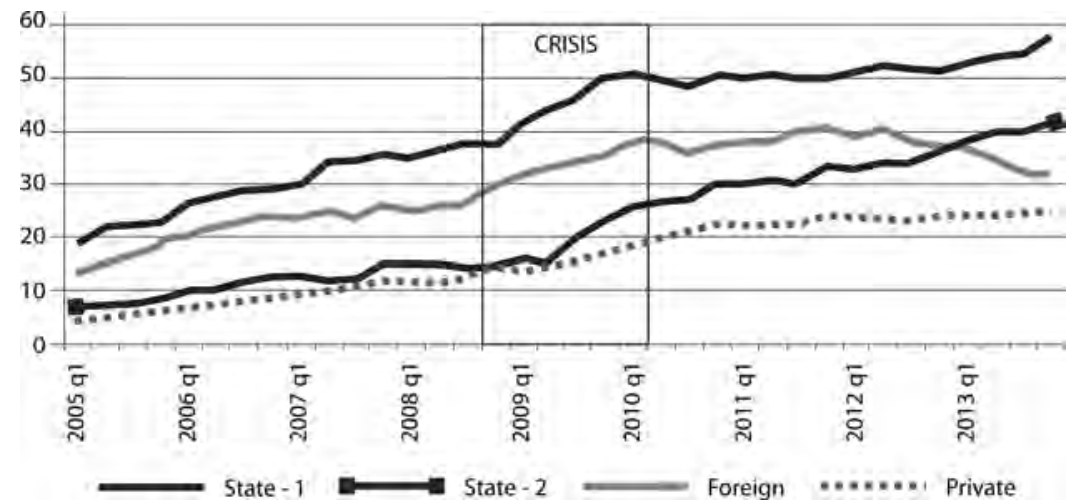

Source: Central Bank of Russia; computations by Mikhail Mamonov 
The contribution of different bank groups to long-term lending also reveals interesting trends. The market share of the core state banks (State-1 in Fig.5) has remained between $60 \%$ and $70 \%$, which was visibly out of line with these banks' share of total assets and total loans in the earlier sub-period but became consistent with it by the end of observations. The contribution of the other state banks is small but tends to rise, and that of foreign banks is falling, in line with general tendency of disengaging from the Russian market.

Fig. 5 - The contribution of bank groups to longer-term (over 3 years) lending in Russia, \%

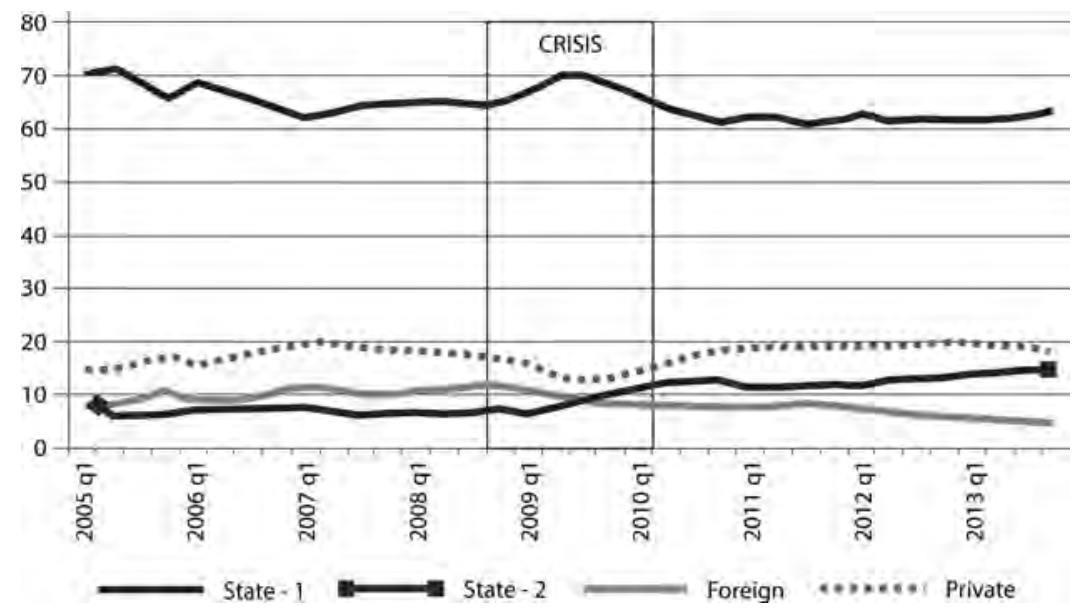

Source: Central Bank of Russia; computations by Mikhail Mamonov

Researchers have noted recently that lending by state banks is counter-cyclical: during the financial crisis of 2008-2009, state banks reduced lending to a lesser extent than other banks in Russia [Fungáčová, Herrala, Weill, 2013] and in other emerging economies [Bertay, Demirgüç-Kunt, Huizinga, 2015]. Our estimates suggest that this is particularly true for longer-term lending. Fig.4 and Fig.5 suggest that during the crisis the core state banks increased the most the share of longer-term loans, thus preempting the shortfall of such maturities in the loan market after the withdrawal of private domestic banks and foreign subsidiaries.

The above-mentioned phenomenon reflects the role of public banks as government agents that carry out certain functions within the transmission mechanism of the monetary policy. In some cases these banks on-lend to secondtier banks, industrial companies and the market at large the resources that monetary authorities make available to them for that purpose. It would however be far from truth that the entire loan portfolio of public banks consists of directed loans. Figuring out the precise proportion of directed loans at each bank is a non-trivial task in the 
absence of a national credit register and the overly formal and superficial disclosure of the ownership structure. ${ }^{3}$

\section{The efficiency of public banks}

Mainstream economics argues that government ownership of banks in developing countries hinders financial development and reduces the average efficiency of the banking sector [La Porta, López-de-Silanes, Shleifer, 2002]. Empirical literature on banking in transition in Central and Eastern Europe offers evidence of lower efficiency of state-owned banks in comparison to other market players [Bonin, Hasan, Wachtel, 2005]. The perennial inefficiency of public banks served as a potent political instrument to promote privatization of those banks in favor of strategic foreign investors. One might assume that directed lending on behalf of the government should depress the efficiency of large state banks in Russia too; there is ample anecdotal evidence of inefficiency and fund abuse in public banks. Actual data from Russia, however, fail to deliver convincing statistical evidence of systematically lower efficiency of public banks. Tab.2 summarizes the return on assets and return on equity, the two main indicators of financial efficiency, at different categories of banks. The scores of the state-controlled banks are consistently above the average for the banking sector, and in most cases these banks actually lead in terms of profitability.

Table 2 - The financial efficiency indicators of Russian banks, 2010-2014 (percent)

\begin{tabular}{l|c|c|c|c|c|c|c|c}
\hline \multirow{2}{*}{ Category of bank } & \multicolumn{4}{|l}{ Return on assets } & \multicolumn{3}{l}{ Return on equity } \\
\cline { 2 - 10 } & 2011 & 2012 & 2013 & 2014 & 2011 & 2012 & 2013 & 2014 \\
\hline State-controlleda & 2.8 & 2.5 & 2.0 & 1.2 & 20.6 & 20.1 & 17.2 & 10.2 \\
\hline Foreign-controlled & 2.4 & 2.5 & 2.2 & 1.6 & 17.4 & 18.8 & 15.1 & 11.1 \\
\hline Large private domestic & 1.7 & 1.9 & 1.6 & 0.1 & 14.2 & 16.0 & 12.9 & 1.2 \\
\hline Small and medium-sized in Moscow & 1.5 & 1.5 & 1.9 & 1.1 & 8.0 & 8.5 & 10.2 & 6.2 \\
\hline $\begin{array}{l}\text { Small and medium-sized in other } \\
\text { regions }\end{array}$ & 1.7 & 1.7 & 1.6 & 1.6 & 10.4 & 10.7 & 10.2 & 9.6 \\
\hline All banks & 2.4 & 2.3 & 1.9 & 0.9 & 17.6 & 18.2 & 15.2 & 7.9 \\
\hline
\end{tabular}

aCBR definition.

Source: CBR, 2015; previous years' editions

The indicators of financial efficiency do not suffice to gauge accurately the comparative efficiency because banks play on an uneven field. State banks have privileged access to cheaper public funds and household savings; they also enjoy greater market power due to their sheer size and the overwhelming market share in various segments of the banking market; foreign-controlled banks can take advantage of their parent group resources and brand strength. Therefore, profitability data must be complemented by the analysis of technical efficiency, i.e. the capacity of the firm to produce the maximum output from the minimum quantity of inputs. Mamonov 
and Vernikov [2015] compute cost efficiency via stochastic frontier technique ${ }^{4}$ and then average individual bank-level cost efficiency levels (SFA scores) across all banks belonging to a particular group. While most of the papers on comparative bank efficiency in transition confront state-owned banks, private domestic banks and foreign banks, we distinguish between two sub-groups of public banks, namely the core state-controlled banks (State-1, comprising Sberbank, VTB, and Russian Agricultural Bank) and other state-controlled banks (State-2). This distinction helps controlling for the broad intra-group heterogeneity in terms of size, scope, business model, and governance.

If we look at the average SFA scores throughout the period of observations (20052013), then private domestic banks lead by the SFA score (81.1\%), followed by State-2 (78.2\%), State-1 (75.5\%) and foreign banks (60.3\%) (Tab.3).

Table 3 - Group-level operating cost efficiency (SFA scores, production approach) as averages of 2005Q1-2013Q4

\begin{tabular}{|c|c|c|c|c|c|c|c|}
\hline \multirow[t]{2}{*}{ Bank group } & \multicolumn{2}{|c|}{ SFA score } & \multirow{2}{*}{$\begin{array}{l}\text { Standard } \\
\text { deviation }\end{array}$} & \multirow[t]{2}{*}{ Min } & \multirow[t]{2}{*}{ Max } & \multirow[t]{2}{*}{ Obs. } & \multirow{2}{*}{$\begin{array}{l}\text { No. of } \\
\text { banks }\end{array}$} \\
\hline & $\%$ & rank & & & & & \\
\hline All groups & 80.1 & - & 14.1 & 2.1 & 99.8 & 29113 & 1139 \\
\hline State-1* & 75.5 & 3 & 18.6 & 34.9 & 98.0 & 108 & 3 \\
\hline State-2** & 78.2 & 2 & 15.2 & 20.8 & 98.7 & 1204 & 61 \\
\hline Foreign & 60.3 & 4 & 19.9 & 6.9 & 97.9 & 1177 & 49 \\
\hline Private & 81.1 & 1 & 13.1 & 2.1 & 99.8 & 26624 & 1065 \\
\hline
\end{tabular}

*core state-controlled banks (Sberbank, VTB, Russian Agricultural Bank. ${ }^{* *}$ other state-controlled banks. Source: Mamonov, Vernikov, 2015

The different efficiency performance of bank groups, and in particular the groups State- 1 and State-2, becomes evident when we add a dynamic scope to our analysis. In order to detect structural changes that the financial crisis of 2008-2009 may have produced, we split the observation period into three sub-periods: pre-crisis, during the crisis, and post-crisis (Fig.6). The graph shows that the ranking in terms of efficiency has changed several times in the process.

The spreads between groups of banks in terms of efficiency turn out to be narrower than hitherto believed, which is consistent with the hypothesis that all players within a banking system are exposed potentially to the best available technology. The ownership status (state-controlled or private) does not preclude a bank from adopting best practices. There is no permanent lead of a particular bank group, and three groups out of four compete for the best efficiency score over the period of observation. Most recently, the core state-controlled banks were more efficient than other statecontrolled banks and nearly as efficient as private domestic banks.

Finally, Figure 6 suggests that bank efficiency rises during a crisis period, which means that economic crises discipline economic agents by forcing them to shed costs 
accumulated during boom periods. We reckon that this empirical finding makes more sense than the results of empirical studies that suggested a falling cost efficiency during crises, which goes against factual evidence of cost cutting at the banks.

Our findings effectively confirm the hypothesis of [Karas, Schoors and Weill, 2010] that private ownership for banks in Russia is no guarantee of superior performance. Large state-controlled banks can also be cost efficient provided that they observe certain proportions in their capitalization, loans-to-assets ratios and some other banklevel characteristics. It, however, contradicts the findings of [Berger, Hasan, Zhou, 2009] with regard to China's Big-4 state banks, albeit on a more distant period.

Fig. 6 - Technical efficiency scores of Russian bank groups (arithmetic averages of SFA scores within each group; ranging from 0 for the least efficient to 100 for the most efficient)

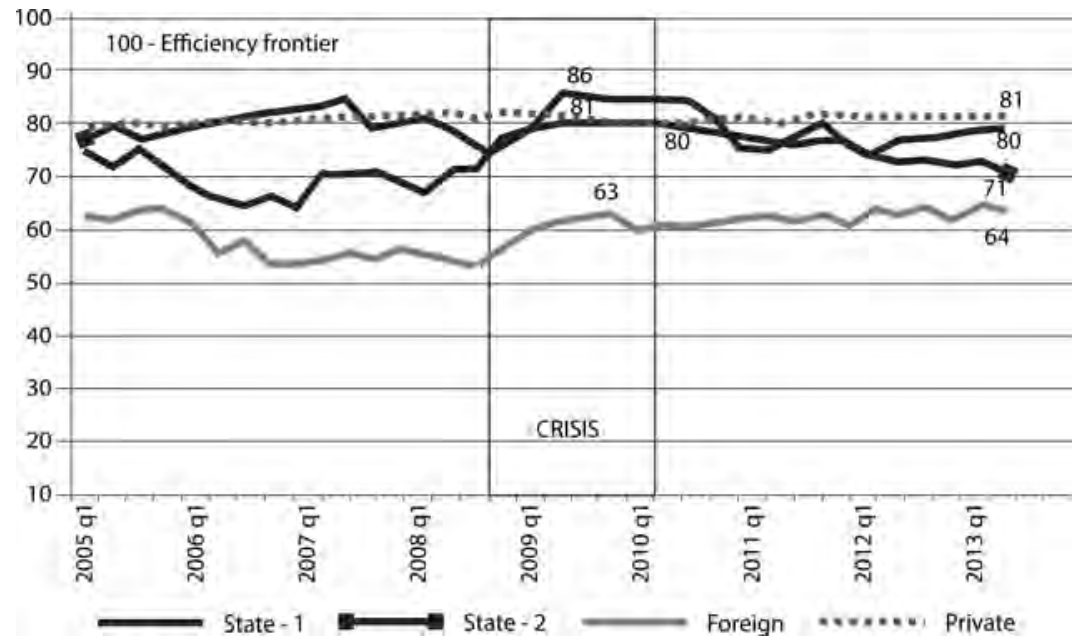

Source: Mamonov, Vernikov, 2015

\section{Comparing the banking models in China and Russia}

Compare the macro-level structure and the core institutions of the banking systems in China and Russia. The main hypothesis is that these two systems are typologically similar. We consider the main institutions, the market structure, the industrial policy of the government, and the banks' involvement in the financing of the non-financial economy. Tab.4 summarizes our findings ${ }^{5}$. 
Table 4 - The comparison of the banking systems of China and Russia

\begin{tabular}{|c|c|c|c|c|}
\hline & China & Russia & $\begin{array}{l}\text { Static: } \\
\text { similarity (+) } \\
\text { or } \\
\text { dissimilarity } \\
(-)\end{array}$ & $\begin{array}{l}\text { Dynamic: } \\
\text { convergence }(+) \text {, } \\
\text { divergence }(-), \text { no } \\
\text { change }(=)\end{array}$ \\
\hline \multicolumn{5}{|l|}{ Institutional structure } \\
\hline The number of commercial banks, and & 541 & $\approx 800$ & - & + \\
\hline the direction of its change & $\uparrow$ & $\downarrow$ & & + \\
\hline \multicolumn{5}{|l|}{ Geographical outreach: bank entities per: } \\
\hline - 1,000 km2; & 9.16 & 2.83 & - & + \\
\hline - 100,000 adults & 7.7 & 38.2 & - & + \\
\hline $\begin{array}{l}\text { Multi-tier and hierarchically organized system } \\
\text { of commercial banks led by the core state- } \\
\text { controlled banks }\end{array}$ & Yes & Yes & + & $=$ \\
\hline A bank-based model of financial intermediation & Yes & Yes & + & $=$ \\
\hline Financial depth (bank assets to GDP), \% & 131.6 & 45.6 & - & + \\
\hline \multicolumn{5}{|l|}{ Market structure and concentration } \\
\hline Supremacy of large state banks & Yes & Yes & + & $=$ \\
\hline \multicolumn{5}{|l|}{ The market share of the: } \\
\hline - core state banks, \% & 45 & 43 & + & - \\
\hline other state-controlled banks, $\%$ & $\approx 50$ & 18 & - & + \\
\hline domestic private banks, $\%$ & 3 & 29 & - & $=$ \\
\hline foreign-controlled banks, $\%$ & 2 & 10 & - & $=$ \\
\hline $\begin{array}{l}\text { Concentration on the commercial banking } \\
\text { market (Top-10), \% }\end{array}$ & 78 & 63 & + & $=$ \\
\hline \multicolumn{5}{|l|}{ The industrial policy of the government } \\
\hline \multicolumn{5}{|l|}{$\begin{array}{l}\text { Nurturing «national champions» within the } \\
\text { public sector: }\end{array}$} \\
\hline - official industrial policy & Yes & No & - & $=$ \\
\hline - the actual policy of the government & Yes & Yes & + & $=$ \\
\hline $\begin{array}{l}\text { The core state-controlled banks are at least as } \\
\text { efficient as other market participants }\end{array}$ & Yes & Yes & + & $=$ \\
\hline $\begin{array}{l}\text { A genuine privatization of the core state- } \\
\text { controlled banks }\end{array}$ & No & No & - & $=$ \\
\hline $\begin{array}{l}\text { A more diversified equity structure of the core } \\
\text { state-controlled banks (corporatization, external } \\
\text { shareholders) }\end{array}$ & Yes & Yes & + & $=$ \\
\hline Favorable treatment of foreign subsidiary banks & Yes & Yes & + & $=$ \\
\hline Favorable treatment of foreign bank branches & Yes & No & - & $=$ \\
\hline An explicit scheme of deposit insurance & $\mathrm{No}^{*}$ & Yes & - & + \\
\hline \multicolumn{5}{|c|}{ Bank involvement in the lending to the non-financial sector } \\
\hline $\begin{array}{l}\text { Domestic bank lending is an important source } \\
\text { of investment into fixed assets of non-financial } \\
\text { companies }\end{array}$ & Yes & No & - & $=$ \\
\hline
\end{tabular}


Table 4 (continued) - The comparison of the banking systems of China and Russia

\begin{tabular}{|c|c|c|c|c|}
\hline & China & Russia & $\begin{array}{l}\text { Static: } \\
\text { similarity (+) } \\
\text { or } \\
\text { dissimilarity } \\
(-)\end{array}$ & $\begin{array}{l}\text { Dynamic: } \\
\text { convergence }(+) \text {, } \\
\text { divergence }(-), \text { no } \\
\text { change }(=)\end{array}$ \\
\hline \multicolumn{5}{|c|}{ Bank involvement in the lending to the non-financial sector } \\
\hline $\begin{array}{l}\text { Lending by the core state-controlled banks } \\
\text { complement budgetary funds invested into fixed } \\
\text { assets of non-financial companies }\end{array}$ & Yes & Yes & + & $=$ \\
\hline $\begin{array}{l}\text { Government bodies interfere into the lending } \\
\text { decisions of the core state-controlled banks }\end{array}$ & Yes & Yes & + & $=$ \\
\hline $\begin{array}{l}\text { The core state-controlled banks combine } \\
\text { commercial banking with development banking }\end{array}$ & Yes & Yes & + & $=$ \\
\hline $\begin{array}{l}\text { Government bodies exert influence on the } \\
\text { lending decisions of nominally independent } \\
\text { banks }\end{array}$ & Yes & No & - & $=$ \\
\hline $\begin{array}{l}\text { Bank lending covers the budget deficit of the } \\
\text { regional and local authorities }\end{array}$ & Yes & $\mathrm{No}^{*}$ & - & + \\
\hline Total & & & $\begin{array}{r}+12 \\
-14\end{array}$ & $\begin{array}{r}+8 \\
=18 \\
-1\end{array}$ \\
\hline
\end{tabular}

* Envisaged.

Sources: CBR, 2015; CBRC, 2014; World Bank, 2013; own research

We find similarities as well as differences, however in dynamics the trend towards convergence prevails. The most visible difference is what seems to be opposite dynamics of the market share of state banks in China and Russia. A few largest statecontrolled institutions constitute the core of the banking sector in both countries. In Russia, the combined market share of Sberbank, VTB and Russian Agricultural Bank reached 43\%. China's 5 «large commercial banks» also keep growing, but their market share is on a gradual decline and already dropped to $53 \%$ of total commercial banking assets and $63 \%$ of employees (Fig.7). The linear trend lines on the chart might cross at some point near $50 \%$ of total assets and then converge. China's falling share of the core state banks can produce an illusion of state withdrawal or divestment from the banking industry, but the absolute majority of joint stock, city and rural commercial banks were also set up by state agencies and enterprises and funded by public capital and remain closely related to the authorities [Okazaki, 2007]. Only five private banks have been authorized in China, of which four are operational (www.cbrc.gov.cn).

The share of the state budget as a source of funds for fixed assets investment is lower in China (4\%-5\%) than in Russia (20\%). I suppose that state budget financing is replaced by lending from state banks that are controlled by government of China. In order to check this, I aggregate the flow of budget funds into fixed assets of nonfinancial companies with the flow of loans disbursed by the core state-controlled banks (expressed through a change in the loan portfolio year-on-year). From 2000 through 2013, the combined flow of funds from both sources averaged $9.4 \%$ percent 
of annual GDP in China and just 4.8\% in Russia. Budget funds and loans from statecontrolled banks do complement each other [Vernikov, 2015a].

Trying to insert the developments in the commercial banking sector into a broader socio-economic context of China and Russia, I rely upon the theory of institutional matrices or TIM [Kirdina, 2014] according to which, the economies of China and Russia both feature a dominance of the institutional matrix that implies centralized nonmarket re-distribution and superior conditional ownership (X-matrix). The leading role of the X-matrix is invariable («path dependence»), so any attempts of double-crossing are doomed, and earlier or later the proportion between cardinal and supplementary institutions will recover. The TIM pre-determines the specific form of resource allocation for the given type of society. The dominant form of resource allocation in an X-economy is centralization and subsequent redistribution under the guidance of the government. The complementary institution in this case rests in the decentralized raising of resources from the financial market and their allocation according to financial efficiency. Correspondingly, the state-controlled banks and their financing for government programs and projects appear as serving the dominant institution of resource allocation for the X-economy. Then privately owned banks' activity in the accumulation of savings and their investment into financial market assets relates to the functioning of the Y-type institution. Together they ensure a needed proportion and balance in the financial system.

Fig. 7 - Market shares of the core state-controlled banks (\% of commercial bank total assets)

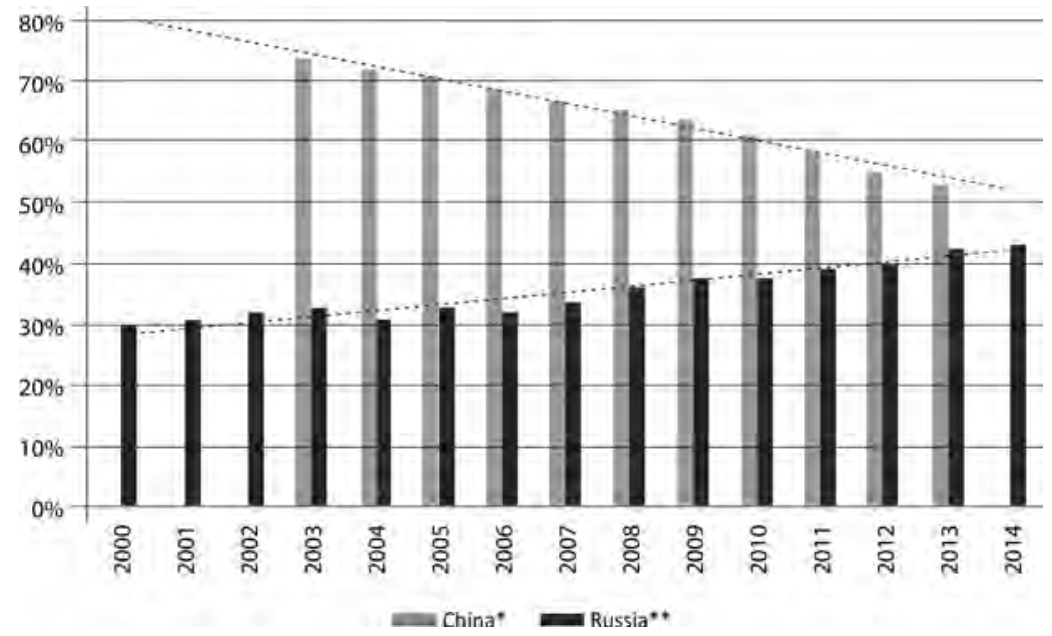

* Industrial and Commercial Bank of China, Agricultural Bank of China, Bank of China, China Construction Bank, and Bank of Communications. ** Sberbank of Russia, Bank VTB, and Russian Agricultural Bank, excluding subsidiaries thereof.

Source: author's calculation based upon data from: (BRC, 2014; The Banker, July 2014; CBR; RIA-Rating (http://riarating.ru/) 
Russia went much further than China in liberalizing its banking sector in the early 1990s. The government withdrew from the reallocation of credit resources and encouraged the breakup of the specialized state-owned banks. At its peak, the number of commercial banks in Russia exceeded 2,400, and absolute majority of them were private. The emerged system, however, was unsustainable and melted down during the crisis of 1998. Thereafter the natural (for Russia) proportion between public and private capital in banking started recovering. The state strengthened its relevance as a regulator, a systemic programmer and a producer of banking services in its capacity of controlling shareholder at the largest commercial banks and development lenders [Kirdina, Vernikov, 2013]. Unlike Russia, China is moving gradually but consistently from a total dominance of one type of institutions, those of centralized reallocation of financial resources, to a more balanced mix that includes resource allocation via market. Private capital remains underrepresented in the banking system, so its share is set to grow. Maintaining a proportion between different types of institutions preserves the stability of the financial system and the trust of the population and sustains economic growth.

\section{Conclusions}

The Russian experiment with private financial intermediation mostly failed as the newly emerged banks indulged in reckless speculation instead of productive activity in the 1990s, which led to the collapse of 1998. Private banking institutions remain fragile and incapable of funding economic growth. The credit for the credit expansion in the 2000s, and especially the longer-term productive lending for investment purposes, goes primarily to the state banks. In the household deposits market, private banks can compete with public banks thank to the deposit insurance system that offsets the general lack of trust towards private banks. The financial crisis of 2008-2009 fostered the restructuring of the banking industry along the lines of state-funded activity of public banks and greater government role in their lending decisions. The core statecontrolled banks carry out two heterogeneous types of activity at the same time, i.e. regular commercial banking and development banking or directed lending. Their role at the current stage increases in the context of re-industrialization and import substitution triggered by the adverse external challenges.

Contrary to the predictions of the mainstream literature on government banking [La Porta, López-de-Silanes, Shleifer, 2002] and banking in transition [Bonin, Hasan, Wachtel, 2005], Russian evidence fails to confirm a systematically inferior efficiency of public banks as compared to domestic private and especially foreign banks. This empirical finding may have policy implications, namely that the issue of privatization of the core public banks migrates from the field of economic rationality firmly into the domain of ideology. 
A comparison of the macro-level structure and the core institutions of the banking systems in China and Russia suggests that these are typologically more similar than different. That refers to the market structure, the industrial policy of the government, and the banks' involvement in the financing of the non-financial economy. China is the appropriate benchmark for Russian banking sector, and not the banking industries of Central European countries fully controlled by foreign capital.

\begin{abstract}
Notes
1 This research was partly supported by the Russian Foundation for Humanities, project No 14-02-00422. I thank Mikhail Mamonov (Center for Macroeconomic Analysis and Short-term Forecasting) for his contribution to the processing of bank-level data.

2 The Central Bank of Russia reports somewhat higher numbers due to the inclusion of foreign bank loans, while our interest is limited to domestic bank lending. On the other hand, the figure might include the loans received from $V$ neshekonombank because the reporting industrial enterprises do not distinguish between the types of banking institutions.

3 The notes to IFRS financial statements do disclose related party lending, but for a state bank the coverage of this item depends on the definition of public property which is quite messy in Russia, especially with regard to state holdings and industrial companies. Formally, Gazprom is not a state-owned company. As a result, related lending is systematically understated.

4 When performing SFA analysis, we control for exogenous factors that can have an impact on efficiency, particularly those related to market power and size [Fungáčová, Solanko, Weill, 2010; Fungáčová, Poghosyan, 2011]. Differently from previous research, we deduct from the gross costs the proceeds of revaluation of foreign currency items on bank balance sheets and the revaluation of securities, in order to control for mostly exogenous factors that have little to do with operational efficiency. There are solid statistical reasons for doing so. The deduction of these two items yields qualitatively better results and enables capturing important effects that would have remain blurred otherwise [Mamonov, Vernikov, 2015].

5 A full version of my paper on China-Russia comparison exists as a working paper [Vernikov, 2014b], while a substantially reduced version was published as [Vernikov, 2015a].
\end{abstract}

\title{
References
}

BERGER A., HASAN I., ZHOU MINGMIN (2009), Bank ownership and efficiency in China: What will happen in the world's largest nation?, Journal of Banking and Finance 33(1): 113-130.

BERTAY A., DEMIRGÜÇ-KUNT A., HUIZINGA H. (2015), Bank ownership and credit over the business cycle: Is lending by state banks less procyclical? Journal of Banking and Finance 50 :

326-339.

BEZEMER D. (2014), Schumpeter might be right again: the functional differentiation of credit, Journal of Evolutionary Economics 24(5): 935-950

BONIN J., HASAN I., WACHTEL P. (2005), Bank performance, efficiency and ownership in transition countries, Journal of Banking and Finance 29(1): 31-53.

CBR (2002), Obzor bankovskogo sektora Rossiyskoy Federacii [Survey of the Banking Sector of the Russian Federation], No 1 (Internet version), Central Bank of Russia, Moscow, November 2002 [in Russian]

CBR (2015), Banking Supervision Report in 2014, Central Bank of Russia, Moscow, 2015 [in Russian]

CBRC (2014), Annual Report 2013, China Banking Regulatory Commission, Beijing.

FUNGÁČOVÁ Z., SOLANKO L., WEILL L. (2010), Market power in the Russian banking industry, International Economics 124(4): 127-145.

FUNGÁČOVÁ Z., POGHOSYAN T. (2011), Determinants of bank interest margins in Russia: Does bank ownership matter?, Economic Systems 35(4): 481-495. 
FUNGÁČOVÁ Z., HERRALA R., WEILL L. (2013), The influence of bank ownership on credit supply: Evidence from the recent financial crisis, Emerging Markets Review 15(2): 136-147.

KARAS A., SCHOORS K., WEILL L. (2010), Are private banks more efficient than public banks? Evidence from Russia // Economics of Transition 18(1): 209-244.

KARAS A., PYLE W., SCHOORS K. (2013), Deposit insurance, banking crises, and market discipline: Evidence from a natural experiment on deposit flows and rates, Journal of Money, Credit and Banking 45(1): 179-200.

KING R., LEVINE R. (1993), Finance and growth: Schumpeter might be right, Quarterly Journal of Economics 108(3): 717-737.

KIRDINA S., VERNIKOV A. (2013), Evolution of the banking system in the Russian context: An institutional view, Journal of Economic Issues 47(2): 475-484.

KIRDINA S. (2014), Institutional matrices theory, or X\&Y Theory: The main provisions and applications, Journal of Institutional Studies 6(3): 12-31.

LA PORTA R., LÓPEZ-DE-SILANES F., SHLEIFER A. (2002), Government ownership of banks, Journal of Finance 57(1): 265-301.

MAMONOV M., VERNIKOV A. (2015), Bank ownership and cost efficiency in Russia, revisited // NRU Higher School of Economics Research Papers WP BRP 46/FE/2015.

OKAZAKI K. (2007), Banking system reform in China:The challenges of moving toward a market -oriented economy // RAND Corporation Occasional Paper Series No RAND/OP-194-CAPP.

RAIFFEISENBANK (2015), CEE Banking Sector Report. Vienna: Raiffeisen Zentralbank Österreich AG and Raiffeisen Centrobank AG.

SCHOORS K. (2003), The fate of Russia's former state banks: Chronicle of a restructuring postponed and a crisis foretold, Europe-Asia Studies 55(1): 75-100.

SCHUMPETER J. (1934), The Theory of Economic Development, Cambridge MA: Harvard University Press.

VERNIKOV A. (2012), The impact of state-controlled banks on the Russian banking sector, Eurasian Geography and Economics 53(2): 250-266.

VERNIKOV A. (2014a), "National champions" in Russia's banking services market, Problems of Economic Transition 57(4): 3-25.

VERNIKOV A. (2014b), China and Russia: Institutional coherence between the banking systems (Economic and Business Working Paper 130). Centre for Comparative Economics (CCE), SSEES, UCL: London.

VERNIKOV A. (2015a), Comparing the banking models in China and Russia: Revisited, Studies on Russian Economic Development 26(2): 178-187.

VERNIKOV A. (2015b), A guide to Russian bank data: Breaking down the sample of banks // SSRN Working Paper Series No 2600738.

WORLD BANK (2013), Financial Development and Structure Dataset (updated Nov. 2013). The World Bank, Washington DC.

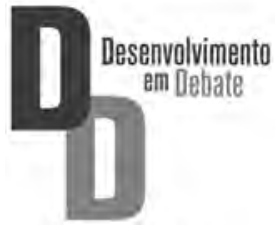

